\title{
Retratos da transformação urbana: 0 uso da fotografia como registro visual do "antes" e "depois" da Lei Cidade Limpa em Londrina
}

\author{
Autora: Fernanda Grosse Bressan \\ Orientador: Paulo César Boni
}

\begin{abstract}
Resumo: Este trabalho demonstra a importância dos registros fotográficos para a documentação das transformações urbanas e preservação da memória. O objeto de estudo é Londrina e os recortes temporais abrangem o centro da cidade antes e depois da Lei Municipal $n^{\circ} 10.966$, sancionada pelo prefeito da cidade em 2 de agosto de 2010. A lei ficou conhecida como "Cidade Limpa" e regulamenta o uso de publicidade externa e fachadas de lojas, indústrias, estabelecimentos comerciais e de prestação de serviços, inclusive a área médica. Lojistas e comerciantes tinham 180 dias para adequar suas publicidades à nova lei, o que prometia transformar a paisagem urbana e devolver aos cidadãos a visão de fachadas arquitetônicas históricas da cidade. O trabalho utiliza referenciais teóricos de fotografia e memória, registra momentos do centro de Londrina no período de mudanças e traz entrevistas com personagens que viveram as alterações por estarem nos locais que passaram pelas transformações.
\end{abstract}

Palavras-chave: Lei Cidade Limpa. Fotografia e Memória. Gatilho da Memória. Publicidade Externa. História de Londrina (PR) 


\title{
Portraits of Urban Transformation: the use of photography as visual record of the "before" and "after" of the law Cidade Limpa in the city of Londrina
}

\begin{abstract}
This work demonstrates the importance of the photographic registers for the documentation of the urban transformations and preservation of the memory. The object of study is the city of Londrina (Paraná State) and the time periods cover its downtown before and after the Municipal Law $n^{\circ}$ 10.966, sanctioned by the mayor of the city on August 2, 2010. The law became known as "Cidade Limpa" (Clean City) and regulates the use of outdoor advertising and shopfronts, factories, stores and service firms, including the medical field. Shopkeepers and merchants had 180 days to adapt their advertisings to the new law, which promised to transform the urban landscape and give back to the citizens the vision of the historical architecture fronts of the city. The work uses theoretical references of photography and memory; it also registers moments from Londrina's downtown in the period of changes and brings interviews with characters who lived the changes because of their presence in locations that passed through transformations.
\end{abstract}

Keywords: Law “Cidade Limpa”. Photography and Memory. Trigger of memory. 